\title{
Karabuğday bitkisinde bor alınımı ve toksitesi üzerine potasyum uygulamalarının etkisi
}

\author{
Damla YAZICI ${ }^{\circledR 1}$, Kürşat KORKMAZ ${ }^{\circledR 1} 1$ \\ ${ }^{1}$ Ordu Üniversitesi, Ziraat Fakültesi, Toprak Bilimi ve Bitki Besleme Bölümü, Ordu
}

Alınış tarihi: 20 Nisan 2020, Kabul tarihi: 5 Haziran 2020

Sorumlu yazar: Kürşat KORKMAZ, e-posta: korkmaz60@gmail.com

\section{Öz}

$\mathrm{Bu}$ çalışmada, karabuğday bitkisinde bor alınımı ve toksitesi üzerine potasyum uygulamalarının etkisinin belirlenmesi amaçlanmıştır. $\mathrm{Bu}$ amaçla, karabuğday bitkisine 6 farklı bor (B) $(0,2.5,5,10,20$ ve $\left.40 \mathrm{mg} \mathrm{B} \mathrm{kg}^{-1}\right)$ ve potasyum (K) $(0,25,50,100,200$ ve $400 \mathrm{mg} \mathrm{K} \mathrm{kg}^{-1}$ ) uygulanarak, tesadüf parsellerinde faktöriyel dağılım deneme desenine göre 3 tekerrürlü olarak sera denemesi yürütülmüștür. Araştırmada; kuru madde, bitkilerde kaldırılan B ve $\mathrm{K}$ miktarları ve bunların bitki dokularındaki konsantrasyonları belirlenmiştir. Bor ve $\mathrm{K}$ uygulamalarının kuru madde, kaldırılan $B$ ve $K$ miktarı ve bunların bitki dokularındaki konsantrasyonları üzerine etkisi istatistiksel olarak önemli bulunmuştur. Karabuğday'da en yüksek kuru madde (23.51 $\mathrm{g} \mathrm{saksi}^{-1}$ ) bor uygulaması yapılmayan kontrol dozunda elde edilirken, en düşük kuru madde (14.87 g saksi $^{-1}$ ) $40 \mathrm{mg} \mathrm{B} \mathrm{kg}^{-1}$ dozunda elde edilmiştir. Karabuğdaya uygulanan $40 \mathrm{mg} \mathrm{kg}^{-1}$ bor dozunda \%37'lik önemli bir kuru madde azalıșına yol açmıştır. Potasyum uygulamasında en yüksek kuru madde (22.74 g saksl $^{-1}$ ) $100 \mathrm{mg} \mathrm{K} \mathrm{kg}^{-1}$ dozunda elde edilirken, en düşük kuru madde (15.99 g saksi $^{-1}$ ) potasyum uygulaması yapılmayan kontrol dozunda elde edilmiştir. Bor ve potasyum arasındaki ilişki incelendiğinde, potasyum uygulanmayan koşullarda bitkilerde bor, $82.81 \mathrm{mg} \mathrm{kg}^{-1}$ olarak belirlenmiștir. Bitkilerde bor konsantrasyonu $50 \mathrm{mg} \mathrm{K} \mathrm{kg}^{-1}$ dozuna kadar artarken (90.94 mg kg-1), $400 \mathrm{mg} \mathrm{K} \mathrm{kg-1}$ dozunda bitki dokularında bor konsantrasyonu (66.90 mg kg-1) önemli bir şekilde azalmıştır. Bitkilerde B konsantrasyonuna benzer şekilde kaldırılan B miktarı da $50 \mathrm{mg} \mathrm{K} \mathrm{kg}^{-1}$ uygulamasına kadar (1.79 $\mathrm{g} \mathrm{saksi}^{-1}$ ) artmış ve $400 \mathrm{mg} \mathrm{K} \mathrm{kg}{ }^{-1}$ dozunda (1.31 g saksı-1) azaltmıştır. Sonuç olarak, karabuğday bitkisinin gelişimi üzerine $B$ ve $K$ uygulamalarının düşük dozlarda olumlu etkileri olduğu gözlenmiştir. Artan dozlarda bor uygulamalarının karabuğday gelişimini olumsuz etkilediği ve yüksek potasyum uygulamalarının bor toksitesinin giderilmesinde olumlu etkileri olduğu söylenebilir.

Anahtar kelimeler: Bor gübrelemesi, potasyum gübrelemesi, bor toksisitesi.

\section{The effect of potassium applications on toxicity and uptake of boron in buckwheat}

\begin{abstract}
In this study, it was aimed to determine the effect of potassium applications on toxicity and uptake of boron in buckwheat. For this purpose, 6 different boron (B) $\left(0,2.5,5,10,20\right.$ and $\left.40 \mathrm{mg} \mathrm{kg}^{-1}\right)$ and potassium $(\mathrm{K})\left(0,25,50,100,200\right.$ and $\left.400 \mathrm{mg} \mathrm{kg}^{-1}\right)$, 3 replicated as greenhouse experiments were conducted according to the factorial distribution experiment design in random plots. In the study; dry matter, $\mathrm{B}$ and $\mathrm{K}$ uptake in plants and their concentrations in plant tissues were determined. The effect of $\mathrm{B}$ and $\mathrm{K}$ applications on dry matter, the amount of $\mathrm{B}$ and $\mathrm{K}$ uptake and their concentrations in plant tissues were found to be statistically significant. The highest dry matter in buckwheat was obtained in non-boron control dose (23.51 $\mathrm{g} \mathrm{pot}^{-1}$ ), while the lowest dry matter (14.87 $\mathrm{g} \mathrm{pot}^{-1}$ ) was obtained in $40 \mathrm{mg} \mathrm{B} \mathrm{kg}^{-1}$ dose. Boron in buckwheat caused a $37 \%$ significant decrease at the dose of 40 mg $\mathrm{kg}^{-1}$ in dry matter. In terms of potassium
\end{abstract}


applications, the highest dry matter (22.74 $\left.\mathrm{g} \mathrm{pot}^{-1}\right)$ was obtained at $100 \mathrm{mg} \mathrm{K} \mathrm{kg}^{-1}$ dose, while the lowest dry matter (15.99 g pot $\left.^{-1}\right)$ was obtained at control dose without potassium. When the relationship between boron and potassium was examined, boron in plants was determined as $82.81 \mathrm{mg} \mathrm{kg}^{-1}$ without potassium. While the boron concentration increased ( $90.94 \mathrm{mg} \mathrm{kg}^{-1}$ ) up to $50 \mathrm{mg} \mathrm{K} \mathrm{kg}^{-1}$ dose, $400 \mathrm{mg} \mathrm{K} \mathrm{kg}$ ${ }^{1}$ dose significantly reduced (66.90 $\left.\mathrm{mg} \mathrm{kg}^{-1}\right)$ boron concentration in plant tissues. Similar to B concentration in plants, the B uptake was increased (1.79 $\mathrm{g} \mathrm{pot}^{-1}$ ) up to $50 \mathrm{mg} \mathrm{K} \mathrm{kg}^{-1}$ application and reduced at a dose of $400 \mathrm{mg} \mathrm{K} \mathrm{kg}^{-1}$ (1.31 $\left.\mathrm{g} \mathrm{pot}^{-1}\right)$. As a result, it is observed that low doses of $\mathrm{B}$ and $\mathrm{K}$ applications have positive effects on the growth of buckwheat. It can be said that increasing doses of boron applications adversely affect the growth of buckwheat and high potassium applications have positive effects on elimination of boron toxicity.

Keywords: Boron fertilization, potassium fertilization, boron toxicity.

\section{Giriş}

Günümüzde tüm dünya ülkelerinin önemle üzerinde durduğu konuların başında yetersiz ve dengesiz beslenme gelmektedir. Artan nüfusun dünyanın besin kaynaklarına yaptığı baskı nedeniyle besin maddesine olan ihtiyaç her geçen gün artarak devam etmektedir ve artan bu ihtiyacın karşılanması zorunludur. Tahıllar tüm dünyada özellikle de gelişmekte olan ülkelerde temel besin kaynağıdır. Ancak son yıllarda meydana gelen çevresel bozulmaların etkisiyle ortaya çlkan iklim değişiklikleri ve bunun yanı sıra yanlış tarımsal uygulamalar sebebiyle ortaya çıkan verim kayıpları dikkate alındığında dünya tahıl üretim alanları ve üretim miktarının da giderek azaldığı görülmektedir. Bu nedenle dünyada giderek artan gıda yetersizliği ve beslenme sorunları insanoğlunun tahıllara alternatif olabilecek farklı ürünler üzerinde yoğunlaşmasına neden olmaktadır. Tahıllara alternatif olabilecek bitkiler arasında çok yönlü kullanım alanına sahip olması ve hızlı gelişme özelliğinden dolayı karabuğday öncelikli olarak araștırılması gereken bitkilerdendir (Min ve ark., 2004; Inamullah ve ark., 2012, Kara ve ark., 2016).

Karabuğday (Fagopyrum esculentum Moench); tek ylllı otsu bir bitki olup, polygonaceae familyasına aittir (Kara ve Telli, 2016). Karabuğday'ı tahıllardan ayıran temel farklılık; tek çenekli (monokotiledon) olmayıp, çift çenekli (dikotiledon) bir bitki olmasıdır
(Dizlek ve ark., 2009). Fagopyrum cinsinin dünyada yaklaşık olarak 15 türü yayılış göstermekte, bunlardan sadece yaygın olan karabuğday (Fagopyrumesculentum Moench) ve tatar karabuğdayının (Fagopyrumtataricum L. Gaertn.) kültürü yapılmaktadır (Ohnishi, 1994). Dünyada karabuğday üretimi 2010 yllında yaklaşık 1.4 milyon ton iken 2017 yllına gelindiğinde 3.8 milyon tona yükselirken dekara ortalama verimi ise yaklaşık 100 kg'dır (Anonim, 2017). Bitkilerde verimin ve kalitenin artırılması için, toprakta noksan olan besin elementlerinin gübreleme yoluyla karşılanması gerekmektedir. Gübreleme bitkilerde verim düşüklüğünün önemli sebeplerinden birisidir. Günümüzde Türkiye'de bitkisel üretim içerisinde kullanılan gübrelerin büyük bir çoğunluğunu sadece $\mathrm{N}, \mathrm{P}$ ve K'lı gübreler oluşturmaktadır. Doğru ve dengeli bir gübrelemenin bitkisel üretimdeki verim artışına etkisi ise \%50-75 arasında olup bazı toprak koşullarında ve ürünlerde bu oran daha da yükselebilmektedir (Șahin, 2016). Üreticiler gübreleme konusunda yeterli bilgi ve beceriye sahip değildir. Topraklarda ve bitkilerde makro elementler ile birlikte zorunlu bulunması gereken mikro elementlere olan ilgi son yllarda daha da dikkat edilmesi gereken bir konu haline gelerek giderek önem kazanmaktadır. Bu husus mikro element uygulamalarının yapılmaması veya uygulandığı zaman ise yanlış zaman ve miktarda uygulamalar nedeniyle ciddi verim kayıplarına yol açmasından kaynaklanmaktadır (Kılıç ve Korkmaz, 2012). Mikro besin elementlerinin noksanlığının yanı sıra fazlalığı da üretimin, verimin ve kalitenin azalmasına neden olmaktadır (Taban ve Erdal, 2000). Mikro besin elementi bozuklukları arasında bor toksitesi ve noksanlığı ise bitkisel üretimi sınırlandıran faktörlerin başında gelmektedir. Türkiye'de özellikle Batı Anadolu Bölgesi'nin dünyadaki B rezervlerinin \%61'ine sahip olduğu ve bölgede B toksisitesinin su kaynaklarını ve tarım alanlarını etkileyen önemli bir problem olduğu bilinmektedir (Nebiler ve ark., 1999; Özkurt, 2000).

Türkiye topraklarının $\mathrm{B}$ yarayışlılığı, yüksek $\mathrm{pH}$ (\%85.5) ve kireç (\%56.4), ağır bünyeli (killi-tın-kil) toprak tekstürü (\%61.9) ve düşük organik madde içeriği (\%94) sebebiyle oldukça düşüktür ve yüksek verim ve kaliteye sahip bir bitkisel üretim modeli için B uygulanması ülkemiz için kaçınılmaz gözükmektedir (Barut ve ark., 2018). Bitkilerin ihtiyaç duydukları B miktarı oldukça azdır ancak yeterlilik ve toksite sınırı arası oldukça dar olması 
nedeniyle ciddi beslenme problemleri ortaya çıkmaktadır.. Normal beslenen bitkiler 20-100 mg $\mathrm{kg}^{-1}$ arasında B içerirler ve bitki kuru maddesinde 20 $\mathrm{mg} \mathrm{kg}^{-1} \mathrm{~B}$ kritik düzey olarak belirtilmiştir (Barut ve ark., 2018). Borun bitkiler için yararlı hale gelmesini etkileyen bazı faktörler vardır. Bunlar; toprağın organik madde içeriği, $\mathrm{pH}, \mathrm{Ca}$ ve $\mathrm{K}$ içeriği, kil tipi ve miktarı ile ıslanma ve kuruma gibi faktörlerdir (Yalın ve ark., 2019). Bu koșullardan farklı olarak aşırı yağıș alan asit topraklarda B borik asit $\mathrm{B}(\mathrm{OH})_{3}$ olarak ylkanarak ortamda uzaklașma eğilimdedir. Toprakların kil ve kireç kapsamı yüksek olduğunda da anyon adsorbsiyonu nedeniyle topraklarda bor yarayışlılığı azalmaktadır (Özkutlu ve ark., 2017a).

Bor bitki bünyesinde de önemli roller üstlenmektedir. Bitkilerde fenolik bileşiklerin ve nükleik asit sentezinde, karbonhidrat ve protein metabolizmasında, şekerlerin taşınmasında, hücre duvarı sentezinde ve yapısında, ligninleşmede, oksin metabolizmasında, polen çimlenmesinde ve polen tüpünün gelişiminde önemli işlevler üstlenmektedir (Zafar-ul-Hy ve ark., 2016). Bitki bünyesinde B'un hareketliliği immobil olarak ifade edilmektedir ve sinırlıdır. Bitkilerin B'u pasif absorpsiyon yolu ile $\mathrm{B}(\mathrm{OH})_{3}$ şeklinde aldıkları bilinmesine rağmen, biraz da olsa aktif absorpsiyon yolu ile $\mathrm{B}(\mathrm{OH})_{4}$ şeklinde de alınır. Borun bitkide yukarı doğru taşınmasında ksilem yoluyla taşınım etkindir bu nedenle bitkinin su alınımı ve transpirasyon bor taşınımında son derece önemlidir. Borun topraklarda mevcut olan yarayışlılığının düşüklüğü ve bitki bünyesine alım ve taşınım sorunlarından dolayı borun yarayıșlılığını ve alınımını olumlu yönde etkileyecek stratejiler üzerinde durulması gereklidir. Bu kapsamda bitki türleri arasındaki farklılıkların dikkate alınması, borlu gübre uygulamaları, toprak düzenleyicilerin kullanılması gibi birçok farklı strateji olmasına karşın bor ve diğer elementler arasındaki ilişkilerin ortaya koyulması pratikte çok daha fazla yarar sağlayacaktır. Bitkilerde B alımı ve taşınımı üzerine topraklarda bulunan diğer besin elementlerinin etkilerinin araştırılması önemli bir konudur. Özellikle borun ksilem ile taşınması ve taşınımın transprasyona bağlı olması nedeniyle bitkilerde osmotik dengenin sağlanmasında etkili olan potasyum ile arasındaki ilişkinin bor yarayışlılığı açısından önemli olabileceğini düșündürmektedir. Borun topraklara uygulanması bitkilerde potasyum içeriğini yükseltirken benzer şekilde de bor ve potasyum arasında karşılılıklı sinerjik ilişki olduğu bilinmektedir (Zafar-ul-Hy ve ark., 2016). Potasyum bitkiler tarafından iyon $\left(\mathrm{K}^{+}\right)$şekilde alınmaktadır ve bitkilerde 200 den fazla enzimin yapisında yer almasının yanı sıra bitkilerde su dengesi ve fotosentez ürünlerinin taşınmasında oldukça etkilidir. Konuyla ilgili literatürler incelendiğinde bor toksite ya da noksanlık sınırları ile ilgili olarak karabuğday bitkisinde yürütülmüş bir araştırmaya rastlanamamıştır. Ayrıca potasyum uygulamalarının bitkilerde stres koşullarına olan olumlu etkileri de düşünüldügünde bor alınımı üzerine yapacağı etkilerin belirlenmesi yararlı olacaktır. $\mathrm{Bu}$ nedenle yürütülen bu çalışmada karabuğday bitkisinde bor alınımı ve toksitesi üzerine potasyum uygulamalarının etkisinin belirlenmesinin yanı sıra karabuğday bitkisinin gelişimi üzerine bor ve potasyum uygulamalarının etkilerinin ortaya konulması amaçlanmıştır.

\section{Materyal ve Metot}

Ordu Üniversitesi araştırma uygulama arazisinden yüzeyden 0-30 cm derinlikten alınan düşük bor ve potasyum içeriğine sahip toprak deneme materyali olarak kullanılmıștır. Araștırmada kullanılacak toprak örneği temiz bir zemin üzerinde gölgede bir hafta süre ile hava kuru hale gelinceye kadar bekletilmiştir. Toprak örneğindeki iri taşlar ve bitkisel atıklar elle ortamdan uzaklaştırılmıştır ve kesekler tahta tokmaklar ile yapısı bozulmayacak şekilde parçalanarak 4 mm'lik elekten geçirilen toprak deneme için hazır hale getirilmiştir. Toprak özelliklerine ait veriler Çizelge 1'de verilmiştir.

Konu ile ilgili deneme, Ordu Üniversitesi Toprak Bilimi ve Bitki Besleme Bölümü araştırma serasında her saksıya $3 \mathrm{~kg}$ toprak gelecek șekilde kurulmuștur. Deneme Aktaş Karabuğday çeşidinde, 6 farklı dozda Bor $\left(0,2.5,5,10,20,40 \mathrm{mg} \mathrm{B} \mathrm{kg}^{-1}\right)$ ve Potasyum $(0$, $25,50,100,200,400 \mathrm{mg} \mathrm{K} \mathrm{kg}^{-1}$ ) uygulanarak tesadüf parsellerinde faktöriyel dağılım deneme desenine göre 3 tekerrürlü olarak yürütülmüştür. Bor kaynağı olarak borik asit $\left(\mathrm{H}_{3} \mathrm{BO}_{3}\right)$ ve potasyum kaynağ olarak $\mathrm{K}_{2} \mathrm{SO}_{4}$ kullanılmıştır. Ayrıca tüm saksılara temel gübreleme olarak çözelti halinde ekimle birlikte $100 \mathrm{mg} \mathrm{kg}^{-1}$ olacak şekilde $\mathrm{N}\left(\mathrm{NH}_{4} \mathrm{NO}_{3}\right)$ ve $100 \mathrm{mg} \mathrm{kg}^{-1} \mathrm{P}\left(\mathrm{CaHPO}_{4} \cdot 2 \mathrm{H}_{2} \mathrm{O}\right)$ verilmiş ve toprakla iyice karıştırılmıştır. Yürütülen saksı denemesinde 8 adet tohum ekilmiş ve çıkış sağlandıktan sonra 3 bitki kalacak şekilde bitkiler seyreltilmiştir. Ekimi takiben saksılar saf su ile sulanmış ve 8 hafta sonunda bitkiler, bor ve potasyuma bağlı olarak gelişim farklılıklarının meydana geldiği dönemde hasat edilmiştir Hasat işlemi gerçekleştikten sonra 
bitki örnekleri saf su ile ylkanarak $65{ }^{\circ} \mathrm{C}$ de sabit ağırlığa gelinciye kadar etüvde kurumaya bırakılmıştır (Kaçar ve İnal, 2008). Bitki örneklerinde kuru madde verimleri belirlendikten sonra agat değirmeninde öğütülmüștür. Öğütülen bitki örneklerinden $0.200 \mathrm{~g}$ tartılarak yüksek sıcaklığa dayanıklı porselen krozelere konmuştur.
Kuru yakma yöntemine göre kül firınında $500{ }^{\circ} \mathrm{C}$ ' de 6 saat süreyle yanan numunelerden elde edilen küle $2 \mathrm{ml} \mathrm{1/3} \mathrm{HCl}$ ilave edilip saf su ile $20 \mathrm{ml}^{\prime}$ ye tamamlandıktan sonra mavi-bant filtre kağıdı ile süzülerek örneklerin analize hazırlama işlemi tamamlanmıştır (Kaçar ve İnal 2008).

Çizelge 1. Deneme toprağının bazı fiziksel ve kimyasal özellikleri

\begin{tabular}{|c|c|c|c|c|c|c|c|c|c|c|c|c|}
\hline Tekstür & $\mathrm{pH}$ & EC & O.M & $\mathrm{CaCO}_{3}$ & $\mathrm{~N}$ & $\mathrm{P}$ & $\mathrm{K}$ & $\mathrm{Fe}$ & $\mathrm{Zn}$ & $\mathrm{Cu}$ & $\mathrm{Mn}$ & $\mathrm{B}$ \\
\hline & & $\mathrm{dS} \mathrm{m}^{-1}$ & & ---\%--- & --- & & -- & -----1 & $g^{-1--}$ & -- & $-\cdots$ & \\
\hline Kumlu Tın & 7.8 & 0.176 & 0.27 & 5.26 & 0.014 & 7.1 & 64.7 & 15.2 & 1.6 & 5.6 & 2.6 & 0.2 \\
\hline
\end{tabular}

Bitki örneklerinde potasyum miktarı Flamme Fotometrede (Kacar ve İnal, 2008), bor analizi ise azometin-H çözeltisi ile oluşturduğu sarı renk kompleksi yoğunluğunun 420 nanometre dalga boyuna ayarlanmış spektrofotometrede belirlenmiștir (Wolf, 1971; Wolf, 1974). Karabuğday tarafindan kaldırılan bor ve potasyum; bitkilerin kuru madde miktarı ile dokularda bulunan besin elementinin konsantrayonu göre (g saksi $^{-1}$ ) hesaplanmıştır. Araştırmada elde edilen veriler SAS v. 9.0 istatistik programında varyans analizine tabi tutulmuş ve ortalamaların karşılaştırılmasında LSD (Least Significant Differences) metodu kullanılmıştır.

\section{Bulgular ve Tartışma}

\section{Karabuğdayda Gövde Kuru Madde Miktarı}

Araștırmada kullanılan karabuğday bitkisinin 6 farklı dozda bor $\left(0,2.5,5,10,20\right.$ ve $\left.40 \mathrm{mg} \mathrm{B} \mathrm{kg}^{-1}\right)$ ve potasyum $\left(0,25,50,100,200\right.$ ve $\left.400 \mathrm{mg} \mathrm{K} \mathrm{kg}^{-1}\right)$ uygulamaları altında ortalama kuru madde miktarları Çizelge 2'de verilmiştir. Yapılan istatistiksel analiz sonucuna göre bor, potasyum ve bor ile potasyum interaksiyonu uygulamalarının karabuğdayda kuru madde miktarı üzerine etkisi önemli $(\mathrm{P}<0.001)$ bulunmuştur.

Çizelge 2. Karabuğday Bitkisinin Kuru Madde Miktarı (g saksı-1)

\begin{tabular}{|c|c|c|c|c|c|c|c|}
\hline & 0 & 2.5 & 5 & 10 & 20 & 40 & Ortalama \\
\hline 0 & $17.70 \mathrm{k}-\mathrm{m}$ & $18.05 \mathrm{j}-\mathrm{m}$ & $17.12 \mathrm{k}-\mathrm{m}$ & $17.08 \mathrm{~lm}$ & $15.96 \mathrm{mn}$ & $10.04 \mathrm{p}$ & $15.99 \mathrm{C}$ \\
\hline 25 & $24.63 \mathrm{ab}$ & 24.33 a-c & 23.54 a-e & 23.46 a-e & $21.00 \mathrm{e}-1$ & $11.00 \mathrm{op}$ & 21.33 B \\
\hline 50 & $25.21 \mathrm{a}$ & $25.40 \mathrm{a}$ & $25.06 \mathrm{a}$ & $23.87 \mathrm{a}-\mathrm{d}$ & $18.91 \mathrm{~h}-\mathrm{l}$ & 13.50 no & $21.99 \mathrm{AB}$ \\
\hline 100 & $24.14 \mathrm{a}-\mathrm{c}$ & 23.69 a-d & $23.25 \mathrm{a}-\mathrm{e}$ & $23.87 \mathrm{a}-\mathrm{d}$ & $21.82 \mathrm{c}-\mathrm{g}$ & $19.67 \mathrm{~g}-\mathrm{k}$ & $22.74 \mathrm{~A}$ \\
\hline 200 & $25.26 \mathrm{a}$ & $24.89 \mathrm{a}$ & $23.02 \mathrm{a}-\mathrm{f}$ & 22.08 b-g & $21.36 \mathrm{~d}-\mathrm{h}$ & $18.65 \mathrm{l}-\mathrm{l}$ & $22.54 \mathrm{~A}$ \\
\hline 400 & $24.14 \mathrm{a}-\mathrm{c}$ & $24.36 \mathrm{a}-\mathrm{c}$ & $24.60 \mathrm{ab}$ & 23.53 a-e & $20.44 \mathrm{f}-\mathrm{j}$ & $16.34 \mathrm{~lm}$ & $22.23 \mathrm{AB}$ \\
\hline Ortalama & $23.51 \mathrm{~A}$ & $23.45 \mathrm{~A}$ & $22.76 \mathrm{AB}$ & $22.31 \mathrm{~B}$ & $19.92 \mathrm{C}$ & 14.87 D & \\
\hline LSD K & *** & 1.05 & & & & & \\
\hline LSD B & $* * *$ & 1.05 & & & & & \\
\hline LSD BxK & $* * *$ & 2.58 & & & & & \\
\hline
\end{tabular}

${ }^{* * *}$ istatiksel olarak $\mathrm{P}<0.001$ düzeyinde önemlidir.

Karabuğdayda bor uygulamalarının bitki kuru madde miktarı üzerine etkileri değerlendirildiğinde en yüksek kuru madde $23.51 \mathrm{~g}$ saksi $^{-1}$ ile bor uygulaması yapılmayan kontrol dozunda ve en düşük kuru madde ise $40 \mathrm{mg} \mathrm{B} \mathrm{kg}^{-1}$ dozunda $14.87 \mathrm{~g}$ saksl $^{-1}$ ile elde edilmiştir (Çizelge 2). Karabuğday bitkisinde kuru madde miktarları bu iki değer arasında dağılım göstermiştir. Özellikle karabuğdayda meydana gelen kuru madde azalışının yüksek bor uygulamasından kaynaklı toksiteye bağlı olarak ortaya çıktığı görülmektedir. Bitki kuru ağırlıkları incelendiğinde $10 \mathrm{mg} \mathrm{kg}^{-1}$ bor dozuna kadar kuru madde bakımından uygulamalar arasında bir farklılık olmadığı gözlenirken artan dozlarda bor ciddi kuru madde azalışlarına yol açmıştır. Karabuğdaya uygulanan bor $20 \mathrm{mg} \mathrm{kg}^{-1}$ 
dozunda $\% 10$ ve $40 \mathrm{mg} \mathrm{kg}^{-1}$ dozunda ise $\% 37$ 'lik önemli bir kuru madde azalışına yol açmıştır. Konuyla ilgili yapılan benzer çalışmalarda karabuğday ile ilgili bir çalıșmaya rastlanmamasına rağmen buğday (Arı Baykal ve Öncel, 2006), ayçiçeği (Bektaş ve Çelik, 2016), çilek (Ozkutlu ve ark., 2017b), fasulye (Cömert ve Kale Çelik, 2017), mısır (Çelik ve ark., 2017) gibi farklı bitkilerde uygulanan bor dozundaki artışa bağlı olarak kuru madde konsantrasyonununda önemli düşüşler olduğu belirtilmiştir.

Karabuğdayda potasyum uygulamalarının bitki kuru madde miktarı üzerine etkileri değerlendirildiğinde en yüksek kuru madde $22.74 \mathrm{~g} \mathrm{saksl}^{-1} 100 \mathrm{mg} \mathrm{K} \mathrm{kg}^{-1}$ dozunda ve en düşük kuru madde ise potasyum uygulaması yapılmayan kontrol dozunda $15.99 \mathrm{~g}$ sakss $^{-1}$ ile elde edilmiştir (Çizelge 2). Karabuğday bitkisinde kuru madde miktarları bu iki değer arasında dağılım göstermiştir. Karabuğdayda potasyum dozları arasında kontrole göre 100 ve 200 mg K kg-1 dozlarında önemli bir artış sağlanmıştır. Potasyum uygulamasının daha da artırılması ise bitkilerde kuru madde üzerine etki etmezken 100 mg kg${ }^{-1} \mathrm{~K}$ dozunda elde edilen kuru maddeye göre bir miktar azalışa yol açmıştır (Çizelge 2). Konuyla ilgili yapılan benzer çalışmalarda karabuğday ile ilgili bir çalışmaya rastlanmamasına rağmen üzüm (Aydın ve ark., 2005), domates (Tuna ve ark., 2016), biber (Kılıç, 2010), ayçiçeği (Bektaș ve Çelik, 2016), mercimek (Tepe ve Aydemir, 2017), soya fasulyesi (Gowthami ve ark., 2018) gibi farklı bitkilerde uygulanan potasyum dozundaki artışa bağlı olarak bitkilerde kuru madde konsantrasyonununda önemli artışlar olduğunu belirtmişlerdir.

Araştırma sonuçları incelendiğinde (Çizelge 2), bor ve potasyum interaksiyonu arasında istatistiksel olarak $\mathrm{P}<0.001$ düzeyinde fark görülmüștür. Çizelge 2 incelendiğinde karabuğday bitkisindeki bor ve potasyum interaksiyonunun kuru madde miktarları $10.04 \mathrm{~g} \mathrm{saksl}^{-1}$ ile $25.40 \mathrm{~g} \mathrm{saksl}^{-1}$ arasında değiştiği görülmektedir. Araştırma sonuçlarına göre; en yüksek kuru madde $25.40 \mathrm{~g} \mathrm{saksl}^{-1}$ ile $2.5 \mathrm{mg} \mathrm{B} \mathrm{kg}^{-1}$ ile $50 \mathrm{mg} \mathrm{K} \mathrm{kg}^{-1}$ interaksiyonundan elde edilirken en düşük kuru madde $10.04 \mathrm{~g}^{\text {saksI }}{ }^{-1}$ ile $40 \mathrm{mg} \mathrm{kg}^{-1}$ dozunda uygulanan bor ile potasyum uygulaması yapilmayan kontrol dozu interaksiyonunda belirlenmiștir. Araștırma sonuçları değerlendirildiğinde, bor ve potasyumun birlikte uygulanması bitki kuru ağırlığında düşük dozlarda olumlu etki gösterirken artan dozlarda bor uygulamalarının karabuğdayda olumsuz etkileri olduğu ancak kontrol ile karşılaştıııldığında potasyum uygulamalarının bu olumsuz etkileri hafifletebileceği gözlenmiştir (Çizelge 2). Sonuçlar irdelendiğinde, en yüksek doz olan $40 \mathrm{mg} \mathrm{kg}^{-1} \mathrm{~B}$ uygulaması ele alındığında kontrol koşullarında $17.70 \mathrm{~g} \mathrm{saksi}^{-1} \mathrm{kuru}$ madde elde edilirken $40 \mathrm{mg} \mathrm{kg}^{-1}$ $B$ dozunda önemli bir düşüş meydana gelerek kuru madde miktarı $10.04 \mathrm{~g} \mathrm{saksl}^{-1}$ olarak belirlenmiștir yine aynı yüksek bor dozuna $100 \mathrm{mg} \mathrm{kg}^{-1} \mathrm{~K}$ ilave edilmesi ile kuru madde miktarı $19.67 \mathrm{~g} \mathrm{saksı}^{-1}$ olarak belirlenmiş̦tir. Araştırma sonuçlarına göre özellikle K ilave edilmesinin yüksek bor koşullarında kuru madde kayıplarını azaltacağı sonucuna varılmıștır. Konuyla ilgili yapılan benzer çalışmalarda karabuğday ile ilgili bir çalışmaya rastlanmamasına rağmen misırda 2.5 ve $5 \mathrm{mg} \mathrm{kg}^{-1}$ bor uygulamaları en yüksek kuru madde verimini üretirken artan dozlarda bor uygulamalarının kuru madde miktarında azalmalara neden olduğu bildirilmiştir (Çelik ve ark., 2017). Mısır bitkisine uygulanan potasyum dozundaki artışa bağlı olarak bitkilerde kuru madde konsantrasyonununda önemli artışlar olduğunu belirtmișlerdir (Demirel ve ark., 2014). Konuyla ilgli olarak, Bektaș ve Çelik, (2016) ayçiçeğinde yaptıkları çalıșmada artan dozlarda bor uygulamalarının bitkilerde kuru madde miktarını önemli ölçüde düşürürken aynı zaman da potasyum alınımını da olumsuz etkilediğini belirtmişlerdir.

\section{Karabuğdayda Bor Konsantrasyonu}

Araştırmada kullanılan karabuğday bitkisinin 6 farklı dozda bor $\left(0,2.5,5,10,20\right.$ ve $\left.40 \mathrm{mg} \mathrm{B} \mathrm{kg}^{-1}\right)$ ve potasyum $\left(0,25,50,100,200\right.$ ve $\left.400 \mathrm{mg} \mathrm{K} \mathrm{kg}^{-1}\right)$ uygulamaları altında ortalama bor konsantrasyonları Çizelge 3'de verilmiştir. Yapılan istatistiksel analiz sonucuna göre bor, potasyum ve bor ile potasyum interaksiyonu uygulamalarının karabuğdayda bor miktarı üzerine etkisi önemli $\quad(\mathrm{P}<0.001)$ bulunmuştur.

Karabuğdayda bor uygulamalarının bitkide bor miktarı üzerine etkileri değerlendirildiğinde en yüksek bor miktarı $164.92 \mathrm{mg} \mathrm{kg}^{-1}$ ile $40 \mathrm{mg} \mathrm{B} \mathrm{kg}^{-1}$ dozunda ve en düşük bor miktarı ise bor kontrol dozunda $32.24 \mathrm{mg} \mathrm{kg}^{-1}$ ile elde edilmiştir (Çizelge 3).

Karabuğday bitkisinde bor miktarları bu iki değer arasında dağılım göstermiștir. Yapılan istatistik analizlerine göre bor uygulamalarını bitki bor miktarı üzerine etkisinin önemli $(\mathrm{P}<0.001)$ olduğu tespit edilmiştir. Yapılan uygulamalara göre bitkide bor miktarları sırasiyla 32.24, 42.29, 49.98, 66.19, 107.68 ve $164.92 \mathrm{mg} \mathrm{kg}^{-1}$ olacak şekilde artan bor dozlarına göre değişiklik göstermiştir. 
Çizelge 3. Karabuğdayda Bor Konsantrasyonu (mg kg-1)

\begin{tabular}{cccccccc}
\hline & 0 & 2.5 & 5 & 10 & 20 & 40 & Ortalama \\
\hline 0 & $23.05 \mathrm{o}$ & $54.73 \mathrm{k}-\mathrm{m}$ & $60.36 \mathrm{j}-\mathrm{l}$ & $90.54 \mathrm{~g}-\mathrm{l}$ & $129.22 \mathrm{c}-\mathrm{e}$ & $138.98 \mathrm{c}-\mathrm{d}$ & $82.81 \mathrm{~A}$ \\
25 & $47.74 \mathrm{l}-\mathrm{n}$ & $38.27 \mathrm{l}-\mathrm{o}$ & $54.05 \mathrm{k}-\mathrm{m}$ & $80.66 \mathrm{~h}-\mathrm{j}$ & $120.48 \mathrm{e}-\mathrm{g}$ & $169.38 \mathrm{a}-\mathrm{b}$ & $83.76 \mathrm{~A}$ \\
50 & $48.56 \mathrm{l}-\mathrm{n}$ & $51.44 \mathrm{k}-\mathrm{m}$ & $55.97 \mathrm{k}-\mathrm{m}$ & $88.34 \mathrm{~g}-\mathrm{l}$ & $122.91 \mathrm{~d}-\mathrm{f}$ & $178.43 \mathrm{a}$ & $90.94 \mathrm{~A}$ \\
100 & $31.10 \mathrm{~m}-\mathrm{o}$ & $40.60 \mathrm{l}-\mathrm{o}$ & $52.95 \mathrm{k}-\mathrm{m}$ & $40.88 \mathrm{l}-\mathrm{o}$ & $105.62 \mathrm{e}-\mathrm{g}$ & $152.01 \mathrm{~b}-\mathrm{c}$ & $70.69 \mathrm{~B}$ \\
200 & $23.05 \mathrm{o}$ & $49.38 \mathrm{k}-\mathrm{n}$ & $49.79 \mathrm{k}-\mathrm{n}$ & $48.97 \mathrm{l}-\mathrm{n}$ & $73.25 \mathrm{l}-\mathrm{k}$ & $164.68 \mathrm{a}-\mathrm{b}$ & $68.19 \mathrm{~B}$ \\
400 & $18.93 \mathrm{o}$ & $19.34 \mathrm{o}$ & $26.75 \mathrm{n}-\mathrm{o}$ & $47.74 \mathrm{l}-\mathrm{n}$ & $102.61 \mathrm{f}-\mathrm{h}$ & $186.03 \mathrm{a}$ & $66.90 \mathrm{~B}$ \\
\hline Ortalama & $32.24 \mathrm{E}$ & $42.29 \mathrm{D}$ & $49.98 \mathrm{D}$ & $66.19 \mathrm{C}$ & $107.68 \mathrm{~B}$ & $164.92 \mathrm{~A}$ & \\
\hline LSD K & $* * *$ & 9.91 & & & & & \\
LSD B & $* * * *$ & & & & & &
\end{tabular}

${ }_{* * *}$ istatiksel olarak $\mathrm{P}<0.001$ düzeyinde önemlidir.

Konuyla ilgili yapılan benzer çalışmalarda karabuğday ile ilgili bir çalışmaya rastlanmamasına rağmen buğday (Taban ve Erdal, 2000, Baykal ve Öncel, 2006; Hamurcu ve ark., 2008), ve misır (Hamurcu ve ark., 2016) bitkilerinde uygulanan bor dozundaki artışa bağlı olarak bitkilerde bor konsantrasyonununda önemli artışlar olduğu belirtilmiştir.

Karabuğdayda potasyum uygulamalarının bitkide bor miktarı üzerine etkileri değerlendirildiğinde en yüksek bor miktarı $90.94 \mathrm{mg} \mathrm{kg}^{-1} 50 \mathrm{mg} \mathrm{K} \mathrm{kg}^{-1}$ dozunda ve en düşük bor miktarı ise $400 \mathrm{mg} \mathrm{K} \mathrm{kg}^{-1}$ dozunda $66.90 \mathrm{mg} \mathrm{kg}^{-1}$ ile elde edilmiștir (Çizelge 3). Karabuğday bitkisinde bor miktarları bu iki değer arasında dağılım göstermiștir. Karabuğdayda artan dozda potasyum uygulamalarının bitki bor miktarı üzerine önemli etkisi olduğu tespit edilmiştir. Araştırma sonuçları incelendiğinde potasyum uygulaması yapılmayan kontrol koşullarında bitkilerde bor konsantarasyonunun $82.81 \mathrm{mg} \mathrm{kg}^{-1}$ olduğu belirlenirken, potasyum uygulamalarının bitkilerde bor konsantrasyonunu $50 \mathrm{mg} \mathrm{K} \mathrm{kg-1}$ uygulamasına kadar artırırken (90.94 mg kg-1) potasyum dozunun daha da artması ile bitki dokularında bor konsantrasyonunun (66.90 $\mathrm{mg} \mathrm{kg}^{-1}$ ) önemli ölçüde azaldığı belirlenmiştir.

Araştırma sonuçları incelendiğinde (Çizelge 3), bor ve potasyum interaksiyonu arasinda istatistiksel olarak $(\mathrm{P}<0.001)$ önemli bir fark olduğu saptanmıştır. Kkarabuğday bitkisindeki bor ve potasyum interaksiyonunun bor konsantrasyonunun $18.93 \mathrm{mg} \mathrm{kg}^{-1}$ ile $186.03 \mathrm{mg} \mathrm{kg}^{-1}$ arasında değiştiğ görülmektedir. Araştırma sonuçlarına göre; en yüksek bitki bor konsantrasyonu $186.03 \mathrm{mg} \mathrm{kg}^{-1}$ ile
$40 \mathrm{mg} \mathrm{B} \mathrm{kg}-1$ ile $400 \mathrm{mg} \mathrm{K} \mathrm{kg}^{-1}$ ve $178.43 \mathrm{mg} \mathrm{kg}^{-1}$ ile $40 \mathrm{mg} \mathrm{B} \mathrm{kg}^{-1}$ ile $50 \mathrm{mg} \mathrm{K} \mathrm{kg}^{-1}$ interaksiyonlarından elde edilirken, en düşük bor konsantrasyonu 18.93 mg kg-1 ile $400 \mathrm{mg} \mathrm{K} \mathrm{kg}^{-1}$ uygulanan bor uygulaması yapılmayan kontrol dozunda belirlenmiștir (Çizelge 3). Potasyum ve bor uygulanmayan koşullarda bitki dokularında $23.05 \mathrm{mg} \mathrm{kg}^{-1}$ bor olduğu saptanırken artan potasyum uygulamaları bor konsantrasyonunu kontrole göre önemli ölçüde artırarak $50 \mathrm{mg} \mathrm{kg}^{-1}$ dozunda $48.56 \mathrm{mg} \mathrm{kg}^{-1} \mathrm{e}$ kadar yükseltmiştir. Potasyumun 100 ve $200 \mathrm{mg} \mathrm{kg}^{-1}$ uygulamaları da kontrole göre bor konsantrasyonunu artırsa da artan potasyum $400 \mathrm{mg} \mathrm{kg}^{-1}$ dozunda kontrole göre azaltarak $18.93 \mathrm{mg} \mathrm{kg}^{-1} \mathrm{e}$ düşürmüştür. Potasyum ve bor arasındaki ilişkinin belirlenebilmesi açısından kuru madde ve bitki dokularında ki B konsatrasyonlarının birlikte değerlendirilmesi oldukça yararlı olacaktır ve bu sonuçlara göre özellikle bor toksitesi olan alanlarda bitkilere potasyum uygulamasının bitki dokularında bor konsantrasyonunu azaltabileceği ve bor fazlalığından kaynaklanan olumsuz koşulları hafifletebileceğini düşündürmektedir.

Araştıma sonuçlarına göre artan dozlarda bor uygulamaları bitki dokularında bor konsantrasyonunu önemli düzeyde artırmıştır. $\mathrm{Bu}$ sonuçlar değerlendirildiğinde karabuğdayda 20 mg B kg-1 uygulanması sonrasında bitki dokularında bulunan $100 \mathrm{mg} \mathrm{kg}^{-1}$ bor konsantrasyonunun kritik seviye olabileceği görülmüştür. Bitki dokularında biriken bor kuru madde veriminde azalmalara yol açarak toksik etkinin ortaya çıkmasına neden olmuştur. Konuyla ilgili olarak yapılan çalışmalarda artan dozlarda bor uygulamalarının bitki dokularında bor konsantrasyonunu artırdığını 
bildirmektedir (Zafar-ul-Hye ve ark., 2016; Çelik ve ark., 2017; Sharma ve ark., 2017). Ayrıca bir çok araştırmada da yüksek potasyum uygulamalarının bor alınımında antogonistik sonuçlar da doğurabileceğini bildirmişlerdir (Tariq ve Mott, 2006; Sharma ve ark., 2017; Sathi Babu ve ark., 2017).

\section{Karabuğdayda Potasyum Konsantrasyonu}

Araştırmada kullanılan karabuğday bitkisinin 6 farklı dozda bor $\left(0,2.5,5,10,20\right.$ ve $\left.40 \mathrm{mg} \mathrm{B} \mathrm{kg}^{-1}\right)$ ve potasyum $\left(0,25,50,100,200\right.$ ve $400 \mathrm{mg} \mathrm{K} \mathrm{kg}^{-1}$ ) uygulamaları altında ortalama potasyum konsantrasyonları Çizelge 4'de verilmiştir. Yapılan istatistiksel analiz sonucuna göre bor, potasyum $(\mathrm{P}<0.001)$ ve bor ile potasyum interaksiyonu $(\mathrm{P}<0.01)$ uygulamalarının karabuğdayda potasyum konsantrasyonu üzerine etkisi önemli bulunmuştur.

Karabuğdayda bor uygulamalarının bitkide potasyum miktarı üzerine etkileri değerlendirildiğinde en yüksek potasyum miktarı

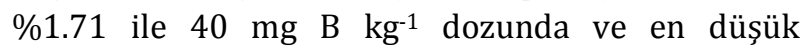
potasyum miktarı ise bor uygulaması yapılmayan kontrol dozunda \%1.31 ile elde edilmiştir (Çizelge 4). Karabuğday bitkisinde potasyum miktarları bu iki değer arasında dağılım göstermiştir. Karabuğdayda potasyum konsantrasyonu artan bor uygulamalarına bağlı olarak önemli düzeyde artış göstermiştir. Konuyla ilgili yapılan benzer çalışmalarda karabuğday ile ilgili bir çalışmaya rastlanmamasına rağmen bor uygulamalarının bitkilerde $\mathrm{K}$ alınımında olumlu etki gösterdiği tespit edilmiştir (Tepe ve Aydemir, 2017).

Karabuğdayda potasyum uygulamalarının bitkide potasyum miktarı üzerine etkileri değerlendirildiğinde en yüksek potasyum miktarı \%1.58 ile 400 mg $\mathrm{K} \mathrm{kg}^{-1}$ dozunda ve en düşük potasyum miktarı ise potasyum uygulanmayan kontrol koșullarında ve 25 ile $50 \mathrm{mg} \mathrm{K} \mathrm{kg}^{-1}$ potasyum uygulaması yapılan dozlarda (sırasıyla \%1.45, \%1.38 ve \%1.39) elde edilmiştir (Çizelge 4). Karabuğday bitkisinde potasyum miktarları bu değerler arasında dağılım göstermiştir. Konuyla ilgili yapılan benzer çalışmalarda karabuğday ile ilgili bir çalışmaya rastlanmamasına rağmen anason (Yağmur, 2008), misır (Martineau ve ark., 2017) ve mercimek (Tepe ve Aydemir, 2017) gibi farklı birçok bitkide potasyum uygulamalarına bağlı olarak potasyum konsantrasyonununda önemli artışlar olduğu belirtilmiştir.

Çizelge 4. Karabuğdayda Potasyum Konsantrasyonu (\%)

\begin{tabular}{|c|c|c|c|c|c|c|c|}
\hline & 0 & 2.5 & 5 & 10 & 20 & 40 & Ortalama \\
\hline 0 & $1.36 \mathrm{~g}-\mathrm{j}$ & $1.37 \mathrm{f}-\mathrm{j}$ & $1.41 \mathrm{f}-\mathrm{j}$ & $1.46 \mathrm{e}-\mathrm{h}$ & $1.51 \mathrm{~d}-\mathrm{f}$ & $1.59 \mathrm{c}-\mathrm{e}$ & $1.45 \mathrm{~B}$ \\
\hline 25 & $1.29 \mathrm{j}$ & $1.30 \mathrm{j}$ & $1.31 \mathrm{l-j}$ & $1.34 \mathrm{~g}-\mathrm{j}$ & $1.36 \mathrm{~g}-\mathrm{j}$ & $1.67 \mathrm{~b}-\mathrm{c}$ & $1.38 \mathrm{C}$ \\
\hline 50 & $1.29 \mathrm{j}$ & $1.30 \mathrm{j}$ & $1.31 \mathrm{~h}-\mathrm{j}$ & $1.36 \mathrm{~g}-\mathrm{j}$ & $1.40 \mathrm{f}-\mathrm{j}$ & $1.67 \mathrm{~b}-\mathrm{c}$ & $1.39 \mathrm{C}$ \\
\hline 100 & $1.31 \mathrm{~h}-\mathrm{j}$ & $1.35 \mathrm{~g}-\mathrm{j}$ & $1.37 \mathrm{f}-\mathrm{j}$ & $1.41 \mathrm{f}-\mathrm{j}$ & $1.62 \mathrm{~b}-\mathrm{d}$ & $1.69 \mathrm{~b}-\mathrm{c}$ & $1.46 \mathrm{~B}$ \\
\hline 200 & $1.27 \mathrm{j}$ & $1.30 \mathrm{l-j}$ & 1.45 e.l & $1.62 \mathrm{~b}-\mathrm{d}$ & $1.66 \mathrm{~b}-\mathrm{c}$ & $1.74 \mathrm{~b}$ & $1.51 \mathrm{~B}$ \\
\hline 400 & $1.34 \mathrm{~h}-\mathrm{j}$ & $1.41 \mathrm{f}-\mathrm{j}$ & 1.57 c-e & $1.49 \mathrm{~d}-\mathrm{g}$ & $1.74 \mathrm{~b}$ & $1.93 \mathrm{a}$ & $1.58 \mathrm{~A}$ \\
\hline Ortalama & $1.31 \mathrm{D}$ & $1.34 \mathrm{D}$ & $1.40 \mathrm{C}$ & $1.45 \mathrm{C}$ & $1.55 \mathrm{~B}$ & $1.71 \mathrm{~A}$ & \\
\hline LSD K & *** & 0.06 & & & & & \\
\hline LSD B & *** & 0.06 & & & & & \\
\hline LSD KxB & $* *$ & 0.15 & & & & & \\
\hline
\end{tabular}

${ }^{* *, * * *}$ sirasıyla istatiksel olarak $\mathrm{P}<0.01$ ve $\mathrm{P}<0.001$ düzeyinde önemlidir.

Araştırma sonuçları incelendiğinde (Çizelge 4), bitkilerde potasyum konsantrasyonu üzerine bor ve potasyumun birlikte uygulanması istatistiksel olarak $(\mathrm{P}<0.01)$ önemli etki göstermiştir. Çizelge 4 incelendiğinde karabuğday bitkisindeki bor ve potasyumun birlikte uygulandığı koşullarda potasyum konsantrasyonu \%1.27 ile \%1.93 arasında değiștiği görülmektedir. Araştırma sonuçlarına göre; en yüksek potasyum konsantrasyonu \%1.93 ile 40 mg B kg-1 ile $400 \mathrm{mg} \mathrm{K} \mathrm{kg}^{-1}$ interaksiyonlarından elde edilirken, en düșük potasyum ise $\% 1.29, \% 1.29$ ve $\% 1.27$ ile $25 \mathrm{mg} \mathrm{K} \mathrm{kg}^{-1}, 50 \mathrm{mg} \mathrm{K} \mathrm{kg}^{-1}$ ve $200 \mathrm{mg} \mathrm{K} \mathrm{kg}^{-1}$ uygulamalarının bor uygulaması yapılmayan kontrol dozu ile interaksiyonunda elde edilmiştir. Konuyla ilgili olarak karabuğdayda bir literatüre rastlanmamıştır. Bu çalışmaya benzer şekilde mısır 
bitkisinde yürütülen bir çalışmada araştırıcılar bor uygulamalarının potasyum alımına etki etmediğini ancak yüksek dozlarda bor uygulamalarının potasyum alınımını olumsuz etkilediğini bildirmişlerdir (Çelik ve ark., 2017).

\section{Karabuğdayda Gövde Tarafından Kaldırılan Bor Miktarı}

Araştırmada kullanılan karabuğday bitkisinin 6 farklı dozda bor $\left(0,2.5,5,10,20\right.$ ve $\left.40 \mathrm{mg} \mathrm{B} \mathrm{kg}^{-1}\right)$ ve potasyum $\left(0,25,50,100,200\right.$ ve $\left.400 \mathrm{mg} \mathrm{K} \mathrm{kg}^{-1}\right)$ uygulamaları altında ortalama gövde tarafından kaldırılan bor miktarları Çizelge 5'de verilmiştir. Yapılan istatistiksel analiz sonucuna göre bor, potasyum ve bor ile potasyum interaksiyonunun karabuğdayda kaldırılan bor miktarı üzerine etkisi önemli $(\mathrm{P}<0.001)$ bulunmuştur.

Karabuğday bitkisinde gövde tarafindan kaldırılan bor miktarları artan bor uygulamalarıyla beraber artmıştır. Deneme sonuçları incelendiğinde kaldırılan bor miktarı ortalama olarak $2.46 \mathrm{mg} \mathrm{saksi}^{-}$

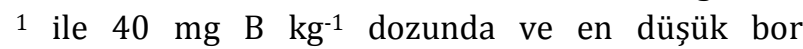
uygulaması yapılmayan kontrol dozunda $0.77 \mathrm{mg}$ saksi $^{-1}$ ile elde edilmiștir (Çizelge 5). Karabuğday bitkisinin gövde tarafından topraktan kaldırdıkları bor miktarları bu iki değer arasında dağılım göstermiştir.

Karabuğday bitkisinde gövde tarafından topraktan kaldırılan bor miktarı üzerine potasyum uygulamalarının etkileri incelendiğinde (Çizelge 5) artan potasyum uygulamalariyla beraber bor alınımında önemli artışlar olduğu belirlenmiştir. Bitkiler tarafından kaldırılan B miktarında 50 mg kg${ }^{1}$ potasyum dozuna kadar önemli bir artış meydana gelirken, bu dozdan sonra $\mathrm{K}$ dozuna bağlı olarak kaldırılan B miktarı azalma eğilimindedir. Araştırma sonuçlarına göre en yüksek kaldırılan bor (1.79 mg B saksi $^{-1}$ ) $50 \mathrm{mg} \mathrm{K} \mathrm{kg}^{-1}$ dozunda ve en düşük kaldırılan bor ise potasyum uygulanmayan kontrol koşullarında (1.23 mg B saksi-1) ve $400 \mathrm{mg} \mathrm{K} \mathrm{kg}^{-1}$ (1.31 mg saksi-1) dozundan elde edilmiştir (Çizelge 5). Karabuğday bitkisinde gövde tarafından topraktan kaldırdıkları bor miktarları bu değerler arasında dağılım göstermiştir.

Karabuğday bitkisinde gövde tarafından topraktan kaldırılan bor miktarı üzerine bor ve potasyum interaksiyonu da istatiksel olarak $(\mathrm{P}<0.001)$ önemli çıkmıştır. Çizelge 5 incelendiğinde, en yüksek kaldırılan bor miktarı 2.99, 3.09, 3.07 mg B saksı $^{-1}$ ile 100,200 ve $400 \mathrm{mg} \mathrm{kg}^{-1}$ potasyum ile en yüksek bor uygulaması olan $40 \mathrm{mg} \mathrm{kg}^{-1}$ bor interaksiyonlarından elde edilirken ve en düşük kaldırılan bor miktarı ise bor ve potasyum uygulaması yapılmayan kontrol dozunda $0.41 \mathrm{mg}$ B saksı ${ }^{-1}$ ile elde edilmiştir. Karabuğday bitkisinde gövde tarafindan topraktan kaldırdıkları bor miktarları bu iki değer arasında dağılım göstermiştir.

Çizelge 5. Karabuğdayda Kaldırılan Bor Miktarı (mg B saksı-1)

\begin{tabular}{|c|c|c|c|c|c|c|c|}
\hline & 0 & 2.5 & 5 & 10 & 20 & 40 & Ortalama \\
\hline 0 & $0.41 \mathrm{n}$ & 0.99 g-m & $1.01 \mathrm{~g}-\mathrm{l}$ & $1.53 \mathrm{~d}-\mathrm{g}$ & $2.06 \mathrm{~b}-\mathrm{d}$ & $1.40 \mathrm{e}-\mathrm{h}$ & $1.23 \mathrm{C}$ \\
\hline 25 & $1.17 \mathrm{f}-\mathrm{j}$ & 0.93 h-n & $1.27 \mathrm{f}-1$ & $1.89 \mathrm{~b}-\mathrm{e}$ & $2.37 \mathrm{~b}$ & $1.86 \mathrm{~b}-\mathrm{e}$ & $1.58 \mathrm{AB}$ \\
\hline 50 & $1.22 \mathrm{~d}-1$ & $1.31 \mathrm{f}-1$ & $1.41 \mathrm{e}-\mathrm{h}$ & $2.11 \mathrm{~b}$ & $2.35 \mathrm{~b}$ & $2.34 \mathrm{~b}$ & $1.79 \mathrm{~A}$ \\
\hline 100 & 0.77 l-n & 0.95 h-n & $1.23 \mathrm{f}-1$ & 0.97 h-m & $2.31 \mathrm{~b}$ & $2.99 \mathrm{a}$ & $1.54 \mathrm{~B}$ \\
\hline 200 & $0.58 \mathrm{k}-\mathrm{n}$ & $1.23 \mathrm{f}-1$ & $1.15 \mathrm{f}-\mathrm{j}$ & $1.08 \mathrm{f}-\mathrm{k}$ & $1.56 \mathrm{c}-\mathrm{f}$ & $3.09 \mathrm{a}$ & $1.45 \mathrm{BC}$ \\
\hline 400 & $0.46 \mathrm{mn}$ & 0.47 l-n & $0.66 \mathrm{j}-\mathrm{n}$ & $1.11 \mathrm{f}-\mathrm{k}$ & $2.09 \mathrm{bc}$ & $3.07 \mathrm{a}$ & $1.31 \mathrm{C}$ \\
\hline Ortalama & $0.77 \mathrm{E}$ & $0.98 \mathrm{DE}$ & $1.12 \mathrm{D}$ & $1.45 \mathrm{C}$ & $2.12 \mathrm{~B}$ & $2.46 \mathrm{~A}$ & \\
\hline LSD K & $* * *$ & 0.22 & & & & & \\
\hline LSD B & $* * *$ & 0.22 & & & & & \\
\hline LSD BxK & $* * *$ & 0.54 & & & & & \\
\hline
\end{tabular}

*** istatiksel olarak $\mathrm{P}<0.001$ düzeyinde önemlidir.

Çizelge 5 incelendiğinde bor uygulanmayan koşullarda karabuğday tarafından kaldırılan bor

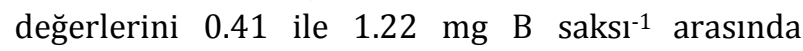
değiştiği görülmektedir. Sonuçlar irdelendiğinde 50 mg kg-1 dozuna kadar uygulanan potasyum topraklarda düşük bor koşullarında bor alınımını artırtığı görülmektedir. Potasyum 50 mg kg-1 dozundan sonra artan dozlarda potasyum bitkilerde bor alınımını azaltmaktadır ancak bu azalıșa rağmen kontrol ile karşılaştırıldığında kaldırılan bor miktarı 
daha yüksek olarak belirlenmiştir. Potasyum uygulamalarının bitkiler tarafından kaldırılan B üzerine olan etkileri dikkat çekicidir ve düşük dozlarda K uygulamaları bor alınımını teşvik ederken artan dozlarda $\mathrm{K}$ uygulanması bor alınımında azalmalar meydana getirmiştir.

Potasyum uygulanmayan koşullarda bor uygulamaları altında karabuğday tarafindan kaldırılan bor değerlerinin 0.41 ile $2.06 \mathrm{mg} \mathrm{B} \mathrm{saksi}^{-1}$ arasında değiștiği görülmektedir. Topraklarda düşük potasyum koşullarında bor uygulaması ile birlikte 20 mg kg-1 B dozuna kadar kaldırılan bor miktarı artarken ortama ilave edilen yüksek seviyede B (40 mg $\mathrm{kg}^{-1}$ ) uygulamasıyla birlikte karabuğdayda kaldırlan B'un $1.40 \quad \mathrm{mg} \quad \mathrm{B} \quad \mathrm{saksi}^{-1}$ olduğu görülmektedir. Kaldırılan B seviyesindeki bu azalışın karabuğdayda ortaya çıkan B toksitesi nedeniyle kuru maddede meydana gelen ciddi azalıştan kaynaklandığı düşünülmektedir. Sonuçlar karabuğday tarafından kaldırılan B açısından değerlendirildiğinde kuru maddede meydana gelen azalma aşırı bor uygulamalarının bitkilerde toksite gösterdiğini ortaya koymaktadır. Bununla birlikte uygulanan B'un karabuğday tarafından yüksek miktarlarda kaldırılarak bitki dokularına alınabileceği belirlenirken yüksek düzeyde kaldırılan B'un bitkilerde kuru madde artışına dönüşmezken bunun yerine olumsuz etkiler ortaya çlkaracağı sonucuna varılmıştır.

\section{Karabuğdayda Gövde Tarafından Kaldırılan Potasyum Miktarı}

Araştırmada kullanılan karabuğday bitkisinin 6 farklı dozda bor $\left(0,2.5,5,10,20\right.$ ve $\left.40 \mathrm{mg} \mathrm{B} \mathrm{kg}^{-1}\right)$ ve potasyum $\left(0,25,50,100,200\right.$ ve $\left.400 \mathrm{mg} \mathrm{K} \mathrm{kg}^{-1}\right)$ uygulamaları altında ortalama gövde tarafından kaldırılan potasyum miktarları Çizelge 6'de verilmiştir. Yapılan istatistiksel analiz sonucuna göre bor, potasyum $(\mathrm{P}<0.001)$ ve bor ile potasyum interaksiyonunun $(\mathrm{P}<0.01)$ karabuğdayda kaldırılan K miktarı üzerine etkisi önemli bulunmuştur.

Karabuğday bitkisinde gövde tarafından kaldırılan potasyum miktarı incelendiğinde (Çizelge 6), bor uygulamalarının kaldırılan potasyum üzerine etkisi $0,2.5,5,10$ ve $20 \mathrm{mg} \mathrm{kg}^{-1}$ dozlarında istatistiksel olarak aralarında fark gözükmeyerek aynı grupta yer alırken, yüksek seviyede (40 mg kg-1) bor uygulandığında önemli düzeyde azalmıştır. Karabuğdayda en yüksek kaldırılan potasyum miktarı kontrol ile aynı grupta olmasına karşın $322.71 \mathrm{mg} \mathrm{K} \mathrm{saksl}^{-1}$ ile $10 \mathrm{mg} \mathrm{kg}^{-1} \mathrm{~B}$ dozunda elde edilirken en düşük kaldırılan potasyum miktarı $257.04 \mathrm{mg} \mathrm{K}$ saksi-1 $^{-1}$ ile $40 \mathrm{mg} \mathrm{B} \mathrm{kg}^{-1}$ dozunda elde edilmiştir (Çizelge 6). Karabuğday bitkisinde gövde tarafindan kaldırılan potasyum miktarları bu iki değer arasında dağılım göstermiştir. Sonuçlar irdelediğinde yüksek bor uygulamaları kaldırılan $\mathrm{K}$ miktarını önemli ölçüde azalmıştır.

Karabuğday bitkisinde gövde tarafından topraktan kaldırılan potasyum miktarları üzerine potasyum uygulamalarının etkileri incelendiğinde (Çizelge 6) artan potasyum uygulamalarıla beraber potasyum alınımında önemli artışlar olduğu belirlenmiştir. Karabuğdayda en yüksek kaldırılan potasyum miktarı $346.17 \mathrm{mg} \mathrm{K}$ saksi $^{-1}$ ile $400 \mathrm{mg} \mathrm{kg}^{-1} \mathrm{~K}$ dozunda ve en düşük kaldırılan potasyum miktarı ise kontrol dozunda $229.51 \mathrm{mg} \mathrm{K}$ saksi $^{-1}$ ile elde edilmiştir (Çizelge 6). Karabuğday bitkisinde gövde tarafindan topraktan kaldırdıkları potasyum miktarları bu iki değer arasında dağılım göstermiştir.

Çizelge 6. Karabuğdayda Kaldırılan Potasyum Miktarı (mg K saksı ${ }^{-1}$ )

\begin{tabular}{|c|c|c|c|c|c|c|c|}
\hline & 0 & 2.5 & 5 & 10 & 20 & 40 & Ortalama \\
\hline 0 & $240.76 \mathrm{ef}$ & $247.42 \mathrm{ef}$ & $238.89 \mathrm{ef}$ & 249.48 ef & 241.13 ef & $159.40 \mathrm{~h}$ & $229.51 \mathrm{C}$ \\
\hline 25 & $317.27 \mathrm{bc}$ & $316.32 \mathrm{bc}$ & $308.14 \mathrm{bd}$ & 316.05 bc & 286.03 c-e & $183.86 \mathrm{gh}$ & $287.94 \mathrm{~B}$ \\
\hline 50 & $324.63 \mathrm{bc}$ & $329.92 \mathrm{bc}$ & $329.72 \mathrm{bc}$ & 324.86 bc & $264.96 \mathrm{~d}-\mathrm{f}$ & $227.86 \mathrm{fg}$ & $300.33 \mathrm{~B}$ \\
\hline 100 & $319.65 \mathrm{bc}$ & $320.02 \mathrm{bc}$ & $319.20 \mathrm{bc}$ & $336.09 \mathrm{a}-\mathrm{c}$ & $353.86 \mathrm{ab}$ & 331.81 bc & $329.62 \mathrm{~A}$ \\
\hline 200 & $316.73 \mathrm{bc}$ & $324.02 \mathrm{bc}$ & $333.32 \mathrm{bc}$ & $357.34 \mathrm{ab}$ & $354.83 \mathrm{ab}$ & $3254 \mathrm{bc}$ & $335.60 \mathrm{~A}$ \\
\hline 400 & $322.88 \mathrm{bc}$ & $3469 \mathrm{ab}$ & $385.45 \mathrm{a}$ & $352.43 \mathrm{ab}$ & $356.78 \mathrm{ab}$ & 314.86 b-d & $346.17 \mathrm{~A}$ \\
\hline Ortalama & $306.99 \mathrm{~A}$ & $313.71 \mathrm{~A}$ & $319.12 \mathrm{~A}$ & $322.71 \mathrm{~A}$ & $309.60 \mathrm{~A}$ & $257.04 \mathrm{~B}$ & \\
\hline LSD K & $* * *$ & 20.55 & & & & & \\
\hline LSD B & $* * *$ & 20.55 & & & & & \\
\hline LSD BxK & $* *$ & 50.33 & & & & & \\
\hline
\end{tabular}

${ }^{* * * * * *}$ istatiksel olarak $\mathrm{P}<0.01$ ve $\mathrm{P}<0.001$ düzeyinde önemlidir. 
Araştırma sonuçları incelendiğinde karabuğday bitkisinde gövde tarafından topraktan kaldırılan potasyum miktarı üzerine bor ve potasyum interaksiyonu istatiksel olarak $(\mathrm{P}<0.01)$ önemli çıkmıştır. Çizelge 6 incelendiğinde, en yüksek kaldırılan potasyum miktarı $385.45 \mathrm{mg} \mathrm{K} \mathrm{saksı}^{-1}$ ile $400 \mathrm{mg} \mathrm{kg}^{-1} \mathrm{~K}$ ile $5 \mathrm{mg} \mathrm{kg}^{-1} \mathrm{~B}$ interaksiyonundan elde edilirken en düşük kaldırılan potasyum miktarı ise $159.40 \mathrm{mg} \mathrm{K}$ saksi $^{-1}$ ile potasyum uygulaması yapılmayan kontrol dozu ile $40 \mathrm{mg} \mathrm{kg}^{-1} \mathrm{~B}$ interaksiyonundan elde edilmiştir (Çizelge 6). Karabuğday bitkisinde gövde tarafından topraktan kaldırdıkları bor ve potasyum interaksiyonu bu iki değer arasında dağılım göstermiştir. Sonuçlar irdelendiğinde potasyum uygulaması yapılmayan kontrol koşullarında uygulanan B karabuğday tarafından kaldırılan potasyum üzerine $20 \mathrm{mg} \mathrm{kg}^{-1} \mathrm{~B}$ dozuna kadar istatistiksel olarak bir etki yapmazken $40 \mathrm{mg} \mathrm{kg}^{-1} \mathrm{~B}$ uygulamasında negatif etki göstererek kaldırılan potasyum da önemli düzeyde azalmaya yol açmıştır. $\mathrm{Bu}$ sonuçlar yüksek dozlarda bor uygulamasının potasyum alınımını olumsuz etkilediğini gösterirken $\mathrm{B}$ ve $\mathrm{K}$ interaksiyonlarıda birlikte değerlendirildiğinde uygun dozlarda ise kaldırılan potasyum ve bor uygulamaları arasında sinerjik bir ilişkinin olduğunu göstermektedir.

\section{Sonuç ve Öneriler}

Araştırma sonuçları incelendiğinde, $B$ ve $K$ uygulamalarının kuru madde, kaldırılan $B$ ve $K$ miktarı ve bunların bitki dokularındaki konsantrasyonları üzerine önemli etkileri olduğu bulunmuştur. Araştıma sonuçlarına göre artan dozlarda bor uygulamaları bitki dokularında bor konsantrasyonunu önemli düzeyde artırmıștır. Bitki dokularında artan B konsantrasyonu kuru madde veriminde azalmalara yol açarak toksik etkinin ortaya çıkmasıyla sonuçlanmıştır. $\mathrm{Bu}$ sonuçlar değerlendirildiğinde karabuğdayda 20 mg B kg-1 uygulanması sonrasında bitkilerde kuru madde önemli ölçüde azalmıştır ve bu uygulama dozunda karabuğday dokularında B konsantrasyonu ortalama $100 \mathrm{mg} \mathrm{kg} \mathrm{kg}^{-1}$ olarak ölçülmüştür. $\mathrm{Bu}$ değerin karabuğday için toksite sınır değeri olabileceği belirlenmiştir. Potasyum alınımı açısından irdelendiğinde yüksek dozlarda bor uygulamasının potasyum alınımını olumsuz etkilediği, uygun dozlarda ise kaldirilan potasyum ve bor uygulamaları arasında sinerjik bir ilişkinin olduğu söylenebilir. Sonuç olarak, karabuğday bitkisinin gelişimi üzerine $\mathrm{B}$ ve $\mathrm{K}$ uygulamalarının düşük dozlarda olumlu etkileri olduğu gözlenirken artan dozlarda bor uygulamalarının karabuğday gelişimini olumsuz etkilediği ve potasyum uygulamalarının bor toksitesinin giderilmesinde olumlu etkileri olduğu söylenebilir.

\section{Teşekkür}

$\mathrm{Bu}$ araştırma, Ordu üniversitesi Bilimsel Araștırmalar Birimi tarafından BY-1726 numaralı proje olarak desteklenmiştir.

\section{Kaynaklar}

Anonim (2017). Food and Agriculture Organization of the United Nations. http://www.fao.org/country profiles/index/en/?iso3=TUR-(Erişim tarihi 05.03.2020).

Arslan, N. (2014). Karabuğday (Fagopyrum esculentum Moench) hem gıda hem de ilaç hammaddesi. Gıda Hattı, 48, 6869.

Baykal, Ş., \& Öncel, I. (2006). Buğday fidelerinin bor toksisitesine toleransında çözünür fenolik ve çözünür protein miktarındaki değişmeler. Fen Bilimleri Dergisi, 27(1), 13.27

Aydın, Ş., Akgül, A., \& Çoban, H. (2005). Alaşehir yöresi bağlarinda yapraktan potasyum (K) uygulamalarinin verim ve bazi kalite özellikleri üzerine etkisi. Celal Bayar Üniversitesi Fen Bilimleri Dergisi, 1(1), 23 -27.

Barut, H., Aykanat, S., Așikli, S., \& Selim, E. (2018). Bitkisel Üretimde Bor. International Journal of Eastern Mediterranean Agricultural Research, 1(1), 33-46.

Beștaș, Z., \& Çelik, H. (2016). Effects of boron resources and increasing application doses on dry matter, boron and potassium uptake of sunflower. Radovi Poljoprivrednog Fakulteta Univerziteta u Sarajevu (Works of the Faculty of Agriculture University of Sarajevo), 61(66 (1)), 228-232.

Cömert, A., ve Kale Çelik, S. (2017). Farklı toprak bünyelerinde sulama suyu bor düzeylerinin fasulye bitkisi verimi üzerine etkilerinin belirlenmesi. Harran Tarım ve Gıda Bilimleri Dergisi, 21(3), 323331.

Çelik, H., Turan, M. A., Aşık, B. B., \& Katkat, A. V. (2017). Evaluation of analytical methods for boron determination in maize shoots. Communications in Soil Science and Plant Analysis, 48(21), 2573-2581.

Demirel, K., Çamoğlu, G., İnalpulat, M., Kahrıman, F., \& Genç, L. (2014). Tuz ve potasyum uygulamalarının misırın yaprak su durumu ile bazı agronomik ve yansıma özelliklerine etkileri. Çanakkale Onsekiz Mart Üniversitesi Ziraat Fakültesi Dergisi, 2 (1), 1-9. 
Dizlek, H., Özer, M.S., İnanç, E., \& Gül, H. (2009). Karabuğday'ın (Fagopyrumes culentum Moench) bileșimi ve gıda sanayinde kullanım olanakları. Glda, 34(5), 317-324.

Gowthami, P., Rao, G. R., Rao, K. L. N., \& Lal, A. M. (2018). Effect of foliar application of potassium, boron and zinc on quality and seed yield in soybean. International J Chemical Stud, 6(1), 142-144.

Hamurcu, A., Gezgin, S., Topal, A., Babaoğlu, B., \& Hakkı, E. E. (2008). Ekmeklik buğdayda bor toksitesine dirençlilik kazandirabilecek genetik kaynaklarin belirlenmesi. Selçuk Üniversitesi Ziraat Fakültesi Dergisi, 22 (46), 43-47.

Hamurcu, M., Özdemir, C., Kocabaş, O., Hakkı, E. E., Demiral, T., \& Gezgin, S. (2016). Toksisite düzeyinde bor uygulamalarının besin çözeltisi koşullarında hibrit mısır çeşitlerinin anatomik özellikleri üzerine etkisi. Bor Dergisi, Boron 1 (2), 53 - 59.

Inamullah I., Saqıb G., Ayub M., Khan A.A., Anwar S., \& Khan S. A. (2012). Response of common buckwheat to nitrogen and phophorus fertilization. Sarhad Journal of Agriculture, 28(2), 171-178.

Kacar, B., \& Inal, A. (2008). Plant analysis. Nobel publication, Ankara.

Kara, B., Çelebi, F. G., Kara, N., \& Atar, B. (2016). Efficiency of different nitrogen forms in buckwheat (Fagopyrum esculentum Moench). Turkish Journal of Agriculture-Food Science and Technology, 4(6), 515-518.

Kara, B., \& Telli, M. (2016). Karabuğdayın (Fagopyrum esculentum Moench) fosfor kullanım etkinliği. Derim, 33(2), 327-336.

Kılıç, R. (2010). Sera koşullarında potasyum uygulamalarının farklı biber genotiplerinin gelişimi üzerine etkisi ve bitkilerde potasyum etkilerinin belirlenmesi. Yüksek Lisans Tezi, Fen Bilimleri Enstitüsü, Ordu Üniversitesi, Ordu.

Kılıç, R., \& Korkmaz, K. (2012). Kimyasal gübrelerin tarım topraklarında artık etkileri. Research Journal of Biology Sciences, 5(2), 87-90.

Martineau, E., Domec, J. C., Bosc, A., Denoroy, P., Fandino, V. A., Lavres Jr, J., \& Jordan-Meille, L. (2017). The effects of potassium nutrition on water use in fieldgrown maize (Zea mays L.). Environmental and experimental botany, 134, 62-71.

Min, W., Yi-min, W., \& Jin-ming, G. (2004). Analysis of fatty acid and unsaponifiable matter from tartary buckwheat oil and buckwheat oil by GC/MS. Advances in Buckwheat Research, 723.

Nebiler, H., Erdoğan, Y., Olgun, A., \& Yerlikaya, C. (1999). The effect of Bon in vineyard. 1st. Symposium on protection of environmental and Erhami Karaçam, Kütahya.

Ohnishi O. (1994). Buckwheat in Karakoram and the Hindukush. Fagopyrum, 14, 17-25.

Özkurt, Ş. (2000). Boron accumulation in carp's tissues (Cypriks carpio L., 1758) in dam lakes Çatören and Kunduzlar (Kırka- Eskișehir). Turk J. Biol., 24, 663676.

Özkutlu, F., Korkmaz, K., Şahin, Ö., Akgün, M., Ete, Ö., Tașkın, B., Özcan, B., \& Aygün, A. (2017a). Ordu ve Samsun yörelerindeki findık bahçelerinin bor beslenme durumunun belirlenmesi. Akademik Ziraat Dergisi, 6(1), 53-62 (2017a).

Özkutlu, F., Ete, Ö., Akgün, M., Akdin, F., Tutuș, Y., \& Özcan, B. (2017b). Boron fertilization effects on strawberry plant for preventing decomposed shaped fruit generation and on mineral content of leaves. Akademik Ziraat Dergisi, 6(2), 153-160.

Sathi Babu, N., Sinha, A. K., Medda, P. S., \& Ghosh, A. (2017). Impact of potassium-boron interaction on leaf nutrient content and nut setting of coconut. International Journal of Current Microbiology and Applied Sciences, 6(12), 4025-4037.

Sharma, R. P., Sepehya, S., Kumar, P., \& Sharma, G. D. (2017). Influence of potassium, zinc and boron on productivity of wheat in an acid Alfisol. Himachal Journal of Agricultural Research, 43(1), 16-22.

Şahin, G. (2016). Türkiye'de gübre kullanım durumu ve gübreleme konusunda yaşanan problemler. Tarım Ekonomisi Dergisi, 22(1), 19-32.

Taban, S., \& Erdal, İ. (2000). Bor uygulamasının değișik buğday çeşitlerinde gelişme ve toprak üstü aksamda bor dağılımı üzerine etkisi. Turkish Journal of Agriculture and Forestry, 24, 255 - 262.

Tariq, M., \& Mott, C. J. B. (2006). Effect of applied boron on the accumulation of cations and their ratios to boron in radish (Raphanus sativus L.). Soil and Environment, 25, 40-47.

Tepe, H. D., \& Aydemir, T. (2017). Farklı konsantrasyonlarda tuz stresi uygulanmış mercimek bitkilerine (Lens culinaris) bor ilavesinin bitki mineral değișimi üzerindeki etkileri. Celal Bayar Üniversitesi Fen Bilimleri Dergisi, 13 (3), 769775.

Tuna, A. L., Yıldıztekin, M., Köşkeroğlu, S., \& Yokaş, İ. (2016). Tuz etkisi altındaki domates bitkisinde potasyum ve kalsiyum antioksidatif sistemi etkiler mi? Türkiye Tarımsal Araştırmalar Dergisi, 4(1), 7178. 
Wolf, B. (1971). The determination of boron in soil extracts, plant materials, composts, manures, water and nutrient solutions. Soil Science and Plant Analysis, 2, 363-374.

Wolf, B. (1974). Improvements in the azomethine-H method for the determination of boron. Communications in Soil Science and Plant Analysis, 5, 39-44.

Yağmur, B. (2008). Farklı seviyelerde uygulanan potasyumun anasonun verim ve yaprak besin maddesi içeriğine etkisi. Ege Üniversitesi Ziraat Fakültesi Dergisi, 46 (1), 17-24.

Yalın, S. B., Orman, Ş., Ok, H., \& Zambak Özgür, A. (2019). Antalya ilinde yetiştirilen kışlık ekmeklik buğdayın bor beslenme durumunun belirlenmesi. Mediterranean Agricultural Sciences, 32(Özel Sayı), 157-161.

Zafar-ul-hye, M., Imran, M., \& Ahmad, M. (2016). Influence of boron fertilization on growth and yield of wheat crop under salt stress environment. Soil \& Environment, 35(2), 181-186. 